\title{
C-X-C Motif Chemokine 16
}

National Cancer Institute

\section{Source}

National Cancer Institute. C-X-CMotif Chemokine 16. NCI Thesaurus. Code C104145.

C-X-C motif chemokine 16 (254 aa, $\sim 28 \mathrm{kDa}$ ) is encoded by the human CXCL16 gene.

This protein may be involved in lymphocyte chemotaxis. 